\title{
To Predict the Tensile Strength of Dissimilar AA6101 and AA6082 by Underwater Friction Stirs Welding
}

\author{
Gaurang K. Champaneri ${ }^{1}$, Amit Patil ${ }^{2}$, Meet Parmar ${ }^{3}$, Pratik Prajapati ${ }^{4}$, Jigar Mistry ${ }^{5}$ \\ ${ }^{1}$ Assistant Professor, Mechanical Engineering Department, R.N.G. Patel Institute of Technology, Bardoli, Gujarat, India \\ 2, 3, 4, 5 UG - Mechanical Engineering, R.N.G Patel Institute of Technology, Bardoli, Gujarat, India
}

\begin{abstract}
This article presents prediction of ultimate tensile strength of joint between aluminium alloys AA6101 and AA6082 by using of underwater friction stirs welding (UWFSW). The considered process parameters are tool rotational speed, tool linear feed and tool shoulder diameter. The change of tool shoulder diameter and other parameters tensile strength varies. The ultimate tensile strength may increase or decrease with increase of tool rotation speed. Also, can decrease with increase of tool shoulder diameter and tool linear speed. Here, tensile strength of the welded alloy of the process, were measured and examined. It has been examined in this experiment that maximum tensile strength of joint is achieved $217 \mathrm{~N} / \mathrm{mm}^{2}$ by applying $18 \mathrm{~mm}$ shoulder diameter with a rotational speed of $1000 \mathrm{rpm} \&$ welding speed of $30 \mathrm{~mm} / \mathrm{min}$. The tensile strength of welded specimens reached in the UWFSW joint is $75-80 \%$ of the parent metal tensile strength. Underwater friction stir welding is more efficient and decent welding technique compare to the other welding categories.
\end{abstract}

Keywords: Dissimilar material, H13 tool, Process parameter, tensile strength, Underwater friction stir welding.

\section{INTRODUCTION}

Friction stir welding was invented by The Welding Institute (TWI) in December 1991. TWI filed successfully for patents in Europe, the U.S., Japan, and Australia. TWI then established TWI Group-Sponsored Project 5651,"Development of the New Friction Stir Technique for Welding Aluminum," in 1992 to further study this technique [1]. Friction stir welding tool has a shoulder its distal end, and a non-consumable welding pin extending downwards centrally from the shoulder. As the rotating tool is brought into contact with the interface between plates, the rotating pin is forced into contact with the material of both plates. The rotation of the pin inserted into the work material and frictional rubbing of the shoulder with the upper surface of the material produces a large amount of frictional heating of both the welding tool and the plate interface [2].

Due to this heat material of the plates is softened in the area near the rotating pin and shoulder, causing commingling of material, which upon hardening, forms a weld. The tool is moved longitudinally along the interface between plates, thereby forming an elongate weld all along the interface between the plates. The welding tool's shoulder prevents softened material from the plates from escaping upwards, and forces the material into the weld joint. When the weld is completed the welding, tool is retracted. Friction stirs welding permits joining of two members in solid state without phase transformation which is characteristic of the fusion welding process which melts and solidifies the parent metal. This method is rapidly practice as an operation towards fabricate the lightweight products in area like aerospace, shipbuilding, marine, automotive, railway and electronics industries. 
DOI: $10.17148 /$ IARJSET.2021.8680

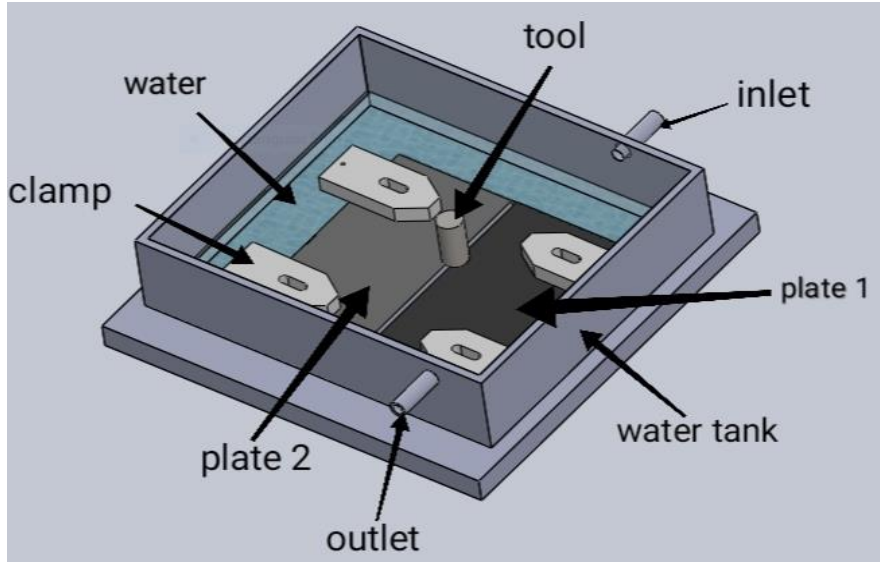

Figure 1 schematic diagram of underwater friction stirs welding (UWFSW)

\section{LITERATURE REVIEW}

1.1 Heena et.al. [3] They work on the Aluminium alloy 6061 and Magnesium alloy AZ31 plates of 6 mm thickness are welded in circular butt joint geometry by friction stir welding (FSW) process, using CNC vertical milling machine. Process parameters like welding speed and tool rotational speed play an important role to acquire a better weld joint for dissimilar metals/materials. In this research work, it is found that welded joint between dissimilar metals alloys $\mathrm{Al} 6061 \& \mathrm{Mg}$ AZ31 can be formed using friction stir welding by choosing suitable tool pin profile and welding parameters. It is suggested that friction stir welding of Aluminium alloy and Magnesium alloy with circular butt joint geometry would be useful in the future for automobile applications by getting the benefits from each material in a functional way.

1.2 Selamat et.al. [4] In this study, the friction stirs welding (FSW) known as the solid-state joining process was extensively used for joining similar and dissimilar $5 \mathrm{~mm}$ aluminium alloy plates. The butt-joint type of similar joints (AA5083-AA5083) and dissimilar joints (AA5083-AA6061) were carried out under the similar welding parameters; $1000 \mathrm{rpm}$ (rotational speed) and $100 \mathrm{~mm} / \mathrm{min}$ (welding speed). They found tensile strength of similar joint and dissimilar joint was $22 \%$ and $19 \%$ lower compared to the base metal of AA5083 and AA6061.

1.3 Sara et.al. [5] In this paper, the feasibility of butt friction stirs welding (FSW) of a metal matrix composite (MMC) with a very high SiC particle content to a monolithic aluminum alloy is tested in this work. It is demonstrated for the first time that sound FSW joints can be obtained between an AA6061 aluminum plate and a thick MMC plate consisting of AA6061 reinforced with 40 vol\% SiC particles. The joints withstand tensile testing.

1.4 H.S. Patil \& S.N. Soman [6] The effect of processing parameters on the mechanical and metallurgical properties of dissimilar joints of AA6082-AA6061 produced by friction stir welding was analyzed in this study. In all the experiments the rotating speed is fixed at $1600 \mathrm{rpm}$. All the welds were produced perpendicularly to the rolling direction for both the alloys. Microhardness (HV) and tensile tests performed at room temperature were used to evaluate the mechanical properties of the joints.

1.5 S.S. Sabari et.al. [7] Under water friction stir welding (UWFSW) is a variant of FSW process which can maintain low heat input as well as constant heat input along the weld line. The heat conduction and dissipation during UWFSW controls the width of TMAZ and HAZ and also improves the joint properties. In this investigation, an attempt has been made to evaluate the mechanical properties and microstructural characteristics of AA2519-T87 aluminium alloy joints made by FSW and UWFSW processes.

\section{EXPERIMENTAL SETUP AND PROCESS}

Experimental setup was recognized using a vertical machining center machine (VMC machine). Not any additional setup is mandatory for friction stir welding excluding tool and fixture, so as to place part in correct location throughout welding as tool move forward, material is forced in flow from leading edge to trailing edge of tool \& material flows around the tool, undergoes extreme level of plastic deformation. As tool passes, weld cools, there by joining the two plates together. 


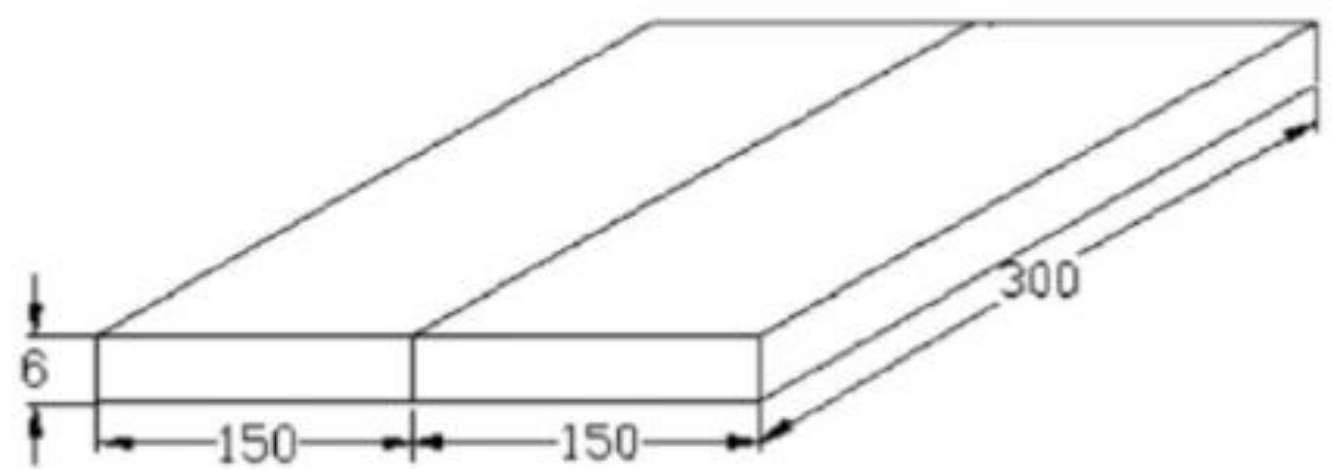

Figure 2 dimension of work piece

The set rolling plates of $6 \mathrm{~mm}$ width, AA6101 \& AA6082 aluminium alloy, have been cut into the essential size (300mm X 150mm). Square butt joint shape generates, as shown in Figure has been arranged to fabricate UWFSW joints. The initial joint formation is obtained by locking the plates in position using mechanical clamps. The route of welding is regular to the rolling direction. Single pass welding technique has been followed to fabricate the joints. Nonconsumable tool finished of Hot Work, Chromium steel is designed and developed to fabricate the joints. The chemical composition of AA6101 \& 6082 is as below.

Table 1 Chemical Compositions of AA6101

\begin{tabular}{|c|c|}
\hline Element & \% Amount \\
\hline Silicon $(\mathrm{Si})$ & $0.70-1.30$ \\
\hline Magnesium $(\mathrm{Mg})$ & $0.60-1.20$ \\
\hline Magnesium $(\mathrm{Mg})$ & $0.40-1.00$ \\
\hline Iron $(\mathrm{Fe})$ & $0.0-0.50$ \\
\hline Chromium $(\mathrm{Cr})$ & $0.0-0.25$ \\
\hline Zinc $(\mathrm{Zn})$ & $0.0-0.20$ \\
\hline Others (Total) & $0.0-0.15$ \\
\hline Titanium (Ti) & $0.0-0.10$ \\
\hline Copper (Cu) & $0.0-0.10$ \\
\hline Other (Each) & $0.0-0.05$ \\
\hline Aluminium (Al) & Balance \\
\hline
\end{tabular}

Table 2 Chemical Compositions of AA6082

\begin{tabular}{|c|c|}
\hline Element & \% Amount \\
\hline Silicon (Si) & $0.30-0.70$ \\
\hline Magnesium (Mg) & 0.50 \\
\hline Magnesium (Mg) & 0.10 \\
\hline Iron (Fe) & 0.03 \\
\hline Chromium (Cr) & 0.03 \\
\hline Zinc ( $\mathrm{Zn})$ & $0.35-0.8$ \\
\hline Others (Total) & 0.10 \\
\hline Titanium (Ti) & 0.3 \\
\hline Copper (Cu) & - \\
\hline Other (Each) & 0.10 \\
\hline Aluminium (Al) & Balance \\
\hline
\end{tabular}

\subsection{Process Parameter}

Underwater Friction stir welding is a sequence of multifaceted physical events with characteristic problems and is controlled by a greater number of factors. A lesser set of factors would give a simpler model, a larger number give more predictive power. However, the greater the number of factors, the more tedious the experimentation and analysis. 
International Advanced Research Journal in Science, Engineering and Technology

Vol. 8, Issue 6, June 2021

DOI: $10.17148 / I A R J S E T .2021 .8680$

Table 3 Input process parameter of UWFSW

\begin{tabular}{|c|c|c|c|c|}
\hline \multirow{2}{*}{$\begin{array}{c}\text { Sr. } \\
\text { No. }\end{array}$} & \multirow{2}{*}{ Input parameter } & \multicolumn{3}{|c|}{ Levels } \\
\cline { 3 - 5 } & Level 1 & Level 2 & Level 3 \\
\hline $\mathbf{1}$ & Shoulder dia. $(\mathbf{m m})$ & 16 & 18 & 20 \\
\hline $\mathbf{2}$ & Feed (mm/rev) & 20 & 25 & 30 \\
\hline $\mathbf{3}$ & Rotational speed (rpm) & 800 & 1000 & 1200 \\
\hline
\end{tabular}

\section{$1.7 \quad$ Tool material}

Selection of the tool material as per review of research papers demonstration the usage of steel tools for plate materials such as Aluminium or Magnesium alloys and Aluminium matrix composites (AMCs) frequently welded by FSW. Steel tools have similarly used for the joining of dissimilar materials in both lap and butt joint shapes. The tool steel-H13 having chemical composition with supplementary carbon content was hardened after making the tool shapes for reducing tool wear throughout FSW process. [4] Using H13 tool for performing our trials which is widely used in real time. High carbon high chromium $(\mathrm{HCHCr})$ tool steel has a remarkably high wear resistance among different tool steel grades. H13 is characterized by shock and abrasion resistance combined with red hardness. It has a chromium composition of $5 \%$ and has high toughness [8].

Applications of UWFSW H13 steel are a chromium-molybdenum hot-worked air hardening steel and are recognized for virtuous elevated-temperature strength, thermal fatigue resistance and wear resistance. The H-13 steel also facilitates a marginally wider range of principal alloying elements availing manufacturers the flexibility of providing mechanical properties for given heat treatments and application. It is widely used in real time applications of friction stir welding. H13 steel is a chromium. The chemical composition of H13 steel tool is as below.

Table 4 H13 tool Material properties

\begin{tabular}{|c|c|c|c|c|c|}
\hline $\mathbf{C}$ & $\mathbf{S i}$ & $\mathbf{M n}$ & $\mathbf{C r}$ & Mo & $\mathbf{V}$ \\
\hline 0.39 & 1.10 & 0.4 & 5.2 & 1.4 & 1.95 \\
\hline
\end{tabular}

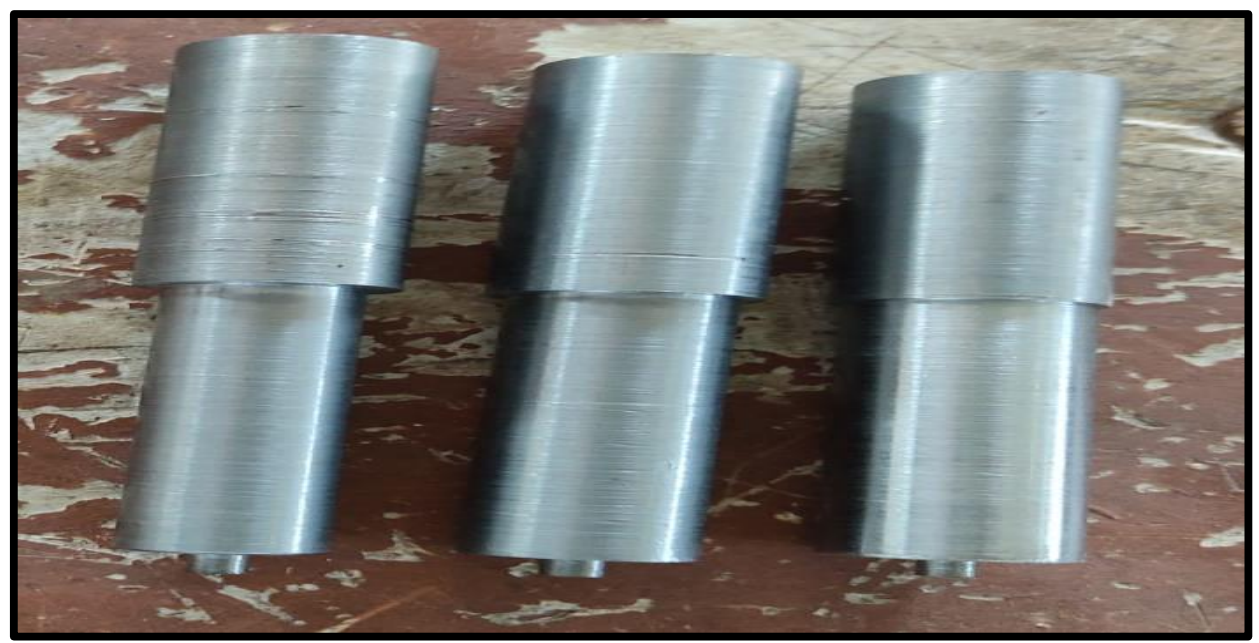

Figure 3 Different diameters of tool using in experiment

1.8

Tensile Test of welded plate

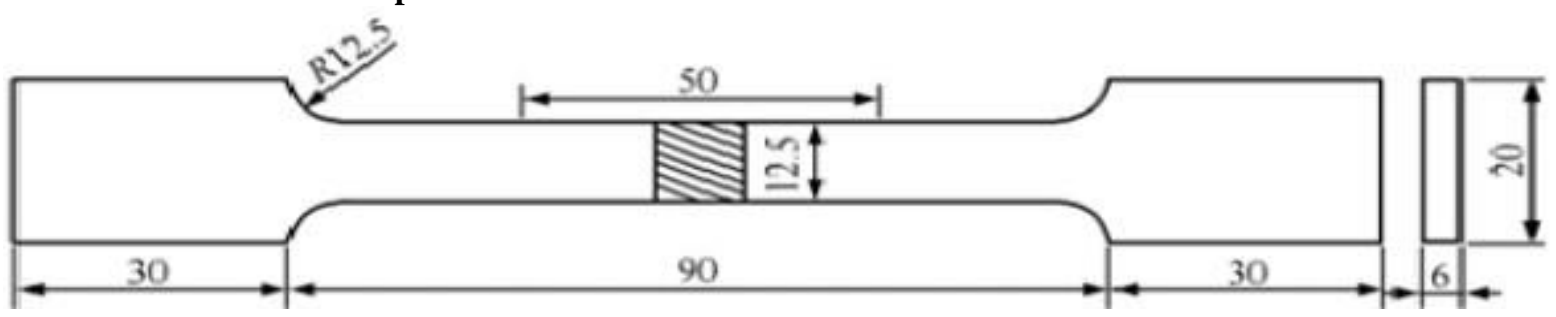

Figure 4 Specimen dimension for tensile strength 
Vol. 8, Issue 6, June 2021

DOI: $10.17148 /$ IARJSET.2021.8680

From all the joints corresponding parameters three specimen are cut to measure the strength of the weld. The specimens are also cut on the milling machine. The all specimens are shown in above fig. Using the UTM (universal testing machine) of 60 Tone load capacity the load (in $\mathrm{KN}$ ) that it can withstand at maximum elongation is measured and dividing it by the cross-sectional area of weld the tensile strength is measured.

\section{RESULT AND DISCUSSION}

\subsection{Planning of experiments}

For developing models based on experimental data, carefully planning of Experiment is essential. The factors considered for the experimentation and analysis of UWFSW between Aluminum alloy AA6101 and AA6082 are tool shoulder diameter, rotational speed and welding speed. It is significant to acquire accurate data with the minimum number of a well-designed experiment by Design of Expert. The Central Composite Design as below.

Table 5 Central Composite Design

\begin{tabular}{|c|c|c|c|c|}
\hline $\begin{array}{c}\text { Std. } \\
\text { Order }\end{array}$ & $\begin{array}{l}\text { Shoulder } \\
\text { Dia. }(\mathrm{mm})\end{array}$ & $\begin{array}{c}\text { Rotational } \\
\text { Speed (RPM) }\end{array}$ & $\begin{array}{c}\text { Welding } \\
\text { Speed }(\mathrm{mm} / \mathrm{min}) \\
\end{array}$ & $\begin{array}{c}\text { Tensile Strength } \\
\left(\mathbf{N} / \mathbf{m m}^{2}\right)\end{array}$ \\
\hline 1 & 16 & 800 & 20 & 180 \\
\hline 2 & 16 & 800 & 40 & 182 \\
\hline 3 & 16 & 1200 & 20 & 194 \\
\hline 4 & 16 & 1200 & 40 & 186 \\
\hline 5 & 16 & 1000 & 30 & 210 \\
\hline 6 & 20 & 800 & 20 & 194 \\
\hline 7 & 20 & 800 & 40 & 206 \\
\hline 8 & 20 & 1200 & 20 & 190 \\
\hline 9 & 20 & 1200 & 40 & 184 \\
\hline 10 & 20 & 1000 & 30 & 192 \\
\hline 11 & 18 & 800 & 30 & 180 \\
\hline 12 & 18 & 1200 & 30 & 184 \\
\hline 13 & 18 & 1000 & 20 & 198 \\
\hline 14 & 18 & 1000 & 40 & 204 \\
\hline 15 & 18 & 1000 & 30 & 216 \\
\hline 16 & 18 & 1000 & 30 & 215 \\
\hline 17 & 18 & 1000 & 30 & 217 \\
\hline 18 & 18 & 1000 & 30 & 216 \\
\hline
\end{tabular}

\section{CONCLUSIONS}

In the sequences of investigational conditions in the existing study, the subsequent conclusions, which can be beneficial for underwater friction stirs welding of square butt weld joint between Aluminium alloy AA6101 and AA6082.

- This investigation shows that the underwater friction stir welding technique can be applied as a sort of approximately perfect shaping technology in material that is practically impossible to weld by other techniques

- It should be clear that, using the new production line, the base material consumption can be significantly reduced compared to the current production route.

- $\quad$ The tensile strength of welded samples stretched in the UWFSW joint is $75-80 \%$ of the parent metal tensile strength.

- $\quad$ Higher welding speed lead to in short exposure time in the weld area with inadequate heat due to underwater environment and poor plastic of the metal and causes about void like defect in the joint. 


\section{International Advanced Research Journal in Science, Engineering and Technology}

Vol. 8, Issue 6, June 2021

DOI: $10.17148 /$ IARJSET.2021.8680

- It has been examined that extreme tensile strength of joint is attained $217 \mathrm{~N} / \mathrm{mm} 2$ with 18 mm shoulder diameter, rotational speed of $1000 \mathrm{rpm}$ and welding speed of $30 \mathrm{~mm} / \mathrm{min}$.

\section{REFERENCES}

[1]. Esther T. Akinlabi, and Stephen A. Akinlabi," Friction Stir Welding Process: A Green Technology", World Academy of Science, Engineering and Technology 71, 2012.

[2]. K. Nagendra Kumar, P. Ravikanth Raju, " Dissimilar Materials of Friction Stir The welding - Overview", International Journal of Engineering Trends and Technology (IJETT) - Volume-44 Number-3 -February 2017

[3]. Heena K Sharma, Kamlesh Bhatt, Krunal Shah, Unnati Joshi," Experimental Analysis of Friction Stir Welding of Dissimilar Alloys AA6061 and Mg AZ31 Using Circular Butt Joint Geometry", ICIAME 2016.

[4]. N.F.M. Selamat, A.H. Baghdadi, Z. Sajuri, and A.H. Kokabi, "Friction stir welding of similar and dissimilar Aluminum alloys for automotive applications", University Malaysia Pahang Publishing, Volume 13, Issue 2 pp. 3401 - 3412, September 2016.

[5]. Sara Señorís-Puentes, Ricardo Fernández Serrano, Gaspar González-Doncel, Jesper Henri Hattel, Oleg V. Mishin, "Microstructure and Mechanical Properties of Friction Stir

[6]. Welded AA6061/AA6061 + 40 vol\% SiC Plates". MDPI, pp.1-11, 23 January 2021

[7]. H. S. Patil, S. N. Soman, "Effect of the weld parameter on mechanical and metallurgical properties of dissimilar joints AA6082-AA6061 in T6 condition produced by UWFSW", Frattura ed Integrità Strutturale, pp 151-160, 24 (2013).

[8]. S. Sree Sabari, S. Malarvizhi, V. Balasubramanian, G. Madusudhan Reddy, "Experimental and numerical investigation on under-water friction stir welding of armour grade AA2519-T87 aluminium alloy". Defence Technology 12, pp 324-33, 2016.

[9]. Kudzanayi Chiteka, "Friction Stir Welding/Processing Tool Materials and Selection", Vol. 2 Issue 11, November - 2013.

[10]. Manikandan N.; Logesh vinoth K.; Nimal kumar R.; Pavithran P.. "Analysis of Mechanical Properties of AA2014 and AA7075 Dissimilar Metals Using Friction Stir Welding". International Research Journal on Advanced Science Hub, 3, Special Issue ICEST 1S, 2021, 34-39. doi: 10.47392/irjash.2021.017

[11]. Aryaman Singh; Gaurav Tamrakar. "Natural Fibre: Fabrication and Testing of Mechanical Properties". International Research Journal on Advanced Science Hub, 3, Special Issue ICOST 2S, 2021, 53-61. doi: 10.47392/irjash.2021.040

[12]. Santhosh Kumar S; Godwin G. "An Enhancement of Properties on Al7075 and Al6061 Dissimilar Materials Welded by TIG Process". International Research Journal on Advanced Science Hub, 2, 6, 2020, 115-121. doi: 10.47392/irjash.2020.47 